\title{
The Effect of Treatment by Intravaginal Progesterone Implants in Postpartum Anestrus Cows on the Changes of the Vaginal Bacterial Load
}

\author{
Syed Ehtisham Hussain Andrabi*, Utsav Sharma, \\ Anil KumarPandey and Sharad Kumar
}

Division of Veterinary Gynaecology and Obstetrics, Faculty of Veterinary Sciences and Animal Husbandry Sher-e-Kashmir University of Agricultural Sciences and Technology of Jammu, R.S. Pura, Jammu, Jammu and Kashmir, India

*Corresponding author

\section{A B S T R A C T}

\section{Keywords}

Vaginal Total Bacterial count, Anestrus, Estrus induction, Progesterone implants

\section{Article Info}

Accepted: 12 August 2020 Available Online: 10 September 2020
The aim of the study was to assess changes in the vaginal bacteria load, at different times following treatment with intravaginal Progesterone implants. Thirty postpartum ( $>70$ days) anestrus crossbred cows were treated with three standard hormonal protocols (CIDR Gr. II, TRIU-B Gr. III and $\mathrm{P}_{4}$ Sponge Gr. IV protocols, $\mathrm{n}=10$ each), and the findings were compared with a group of untreated $(n=10)$ anestrus cows which were inserted with blank sponge (containing no $\mathrm{P}_{4}$ ). Vaginal swabs were collected from each treated cow, prior to insert/sponge insertion and at the time of insert/sponge with draw a land on the day of estrus for bacterial load. The total bacteria count obtained from swabs collected at implant insertion showed no significant difference between CIDR $\left(2.15 \pm 0.53 \mathrm{X} 10^{4}\right)$, TRIU-B $\left(2.14 \pm 0.40 \times 10^{4}\right)$ and $\mathrm{P}_{4}$ Sponge $\left(2.33 \pm 0.68 \times 10^{4}\right)$ implants as well as Control group $\left(2.24 \pm 0.92 \times 10^{4}\right)$ and increased significantly in all groups $(\mathrm{P}<0.01)$ at the time of implant removal viz. $1.80 \pm 0.35 \times 10^{5}, 2.22 \pm 0.57 \times 10^{5}, 2.58 \pm 0.71 \times 10^{5}$ and $2.36 \pm 0.63 \times 10^{5}$ respectively in CIDR, TRIU-B, $\mathrm{P}_{4}$ Sponge, and control groups. As expected, after 48 hours of implant removal, total bacteria count obtained showed no significant difference $(2.71 \pm$ $0.71 \times 10^{4}, 2.85 \pm 0.78 \times 10^{4}$ and $2.96 \pm 1.2 \times 10^{4}$ ) with that of obtained before implant insertion in all the groups of animals but in control group (placebo) the total bacterial count was significantly $(\mathrm{P}<0.01)$ higher $\left(2.02 \pm 0.25 \times 10^{5}\right)$ even after 48 hours after the implant removal. Furthermore, there was no significant difference in total bacterial count at the time of insertion, removal and 48 hours after insertion between CIDR, $\mathrm{P}_{4}$ Sponge and TRIU-B groups but the total bacterial count in control group was significantly higher $(\mathrm{P}<0.001)$ at 48 hours after sponge removal than those of CIDR, $\mathrm{P}_{4}$ Sponge and TRIU-B groups $(\mathrm{P}<0.01)$.

\section{Introduction}

A long postpartum interval is a major problem that limits the improvement of reproductive efficiency of dairy cows under tropical conditions (Shart et al., 1990; Williams, 1990). Protocols with the use of intra-vaginal progesterone implants have been widely used worldwide and represent an important tool to improve reproductive efficiency in 
commercial dairy herds (Norman et al., 2009). However, some cows that received intravaginally devices presented vaginitis (Walsh et al., 2008) that interfered negatively with pregnancy rate (Mansano et al., 2013). At the time of insertion of $\mathrm{P}_{4}$ insert the chances of introduction of microorganisms into the vagina of cow gets increased particularly when hygienic conditions are not maintained during insertion. Relatively little information is available regarding the effects of exogenous progesterone supplementation on the vaginal microflora of early postpartum cows. The effect of hormones, as well as the mechanical presence of the devices, may predispose the cattle to purulent vaginitis (Manes et al., 2010; Penna et al., 2013). This infection is often due to proliferation of the local microbiota and is typically characterized by erythema, a purulent vaginal discharge and abundant vaginal leukocytes (Manes et al., 2010). According to Suárez et al., (2006), although the bacterial population increases temporarily, it returns to its normal values two days after sponge removal.

The vagina of cattle, contains mixed microbial flora consisting of aerobic, strict anaerobic and facultative anaerobic organisms. Under natural conditions, the environment of the bovine vagina is stable and does not allow excessive growth of pathogenic, potentially pathogenic or saprophytic organisms (Hafez, 1993; Hafez and Hafez, 2002 and Otero et al., 2000). There are few studies in postpartum cattle regarding bacterial count of vagina. Additionally, there is a lack of literature about the effects of progestagen impregnated implants on the total bacterial count. Therefore, the purpose of the current experiment was to conduct the quantitative analysis of bacteria from vagina of cattle associated with the use of different intravaginal implants in postpartum anestrus cows subjected to estrus induction.

\section{Materials and Methods}

\section{Animals}

The experimental animals were selected from villages of Jammu and Samba districts of J\& $\mathrm{K}$. The cattle were selected through door to door survey of livestock of some villages and ruling out the cyclic, pregnant, anestrus or repeat breeders through gynaeco-clinical examinations. Only animals without clinical disorders were included. Total 40 anestrus cattle with more than 70 days postpartum period were selected.

\section{Experimental design}

The anestrus cows were randomly divided in to four groups, three treatments $(n=10)$ and one untreated anestrus control $(n=10)$ and were managed with three different hormonal regimens. In 30 anestrus cattle, Progesterone implants (CIDR, TRIU B and Progesterone sponge) were inserted intravaginally on day 0 . The implantswere removed on day 9and on the same day $\mathrm{i} / \mathrm{m}$. Inj. of $600 \mathrm{IU}$ of PMSGleCG was given on followed by AIat detected heat 48-72 hours later. Vaginal swabs (duplicate) were collected on days 0(insertion of implants), 9(removal of implants) and 11/12(estrus).

\section{Bacteriology}

The vulvar area was washed with water followed by surgical spirit and then then a sterile pressed cotton swabs $\left(1 \mathrm{~cm}^{3}\right)$, moistened with saline $(0.9 \% \mathrm{NaCl}$; w/v) swab was inserted along the dorsal vaginal wall to approximately $10 \mathrm{~cm}$ cranial to the vulva, kept there for at least 30 seconds (Fig. 1). Upon collection, samples were placed individually into sterile tubes containing 10 $\mathrm{ml}$ of saline solution, which were kept in ice until arrival at the Public Health Laboratory. For total bacterial count (colony forming 
units; CFU/mL), the first vaginal swab was vigorously homogenized by mechanical vortexing in order to suspend the bacteria. The resulting suspension was serially diluted from $10^{-1}$ to $10^{-6}$ (Fig. 2A)., and aliquots each of $0.1 \mathrm{ml}$ dilution were inoculated in duplicate with sterile ' $L$ ' shaped glass rod under laminar flow in Petri dishes containing standard plate count media for 24 hours in a bacteriological incubator at $37{ }^{\circ} \mathrm{C}$ (Fig. 2). The total bacterial count $(\mathrm{CFU} / \mathrm{mL})$ was done using a manual bacterial colony count procedure according to Koneman et al., (1983) (Fig. 2B). The total bacterial count expressed as colony forming units $(\mathrm{CFU} / \mathrm{ml})$ was expressed as number of colonies forming units per $\mathrm{ml}$ of vaginal fluid.

$\mathrm{CFU} / \mathrm{ml}$ of original sample $=$ Colonies counted under colony counter Inoculum size (ml) x Dilution Factor

\section{Statistical analysis}

The data generated on Bacterial load of vagina were analysed statistically using standard procedures (CRD, ANOVA: 1 . Multivariate Post Hoc Multiple Comparisons for observed means) SPSS 16.00 Statistics (Snedecor and Cochran, 1986), to know the variations within and between groups for each trait. A value of $\mathrm{P}<0.05$ was considered to be statistically significant.

\section{Results and Discussion}

The total bacteria count obtained from swabs collected at implant insertion showed no significant difference between CIDR $(2.15 \pm$ $\left.0.53 \times 10^{4}\right)$, TRIU-B $\left(2.14 \pm 0.40 \times 10^{4}\right)$ and $\mathrm{P}_{4}$ Sponge $\left(2.33 \pm 0.68 \times 10^{4}\right)$ implants as well as Control group $\left(2.24 \pm 0.92 \times 10^{4}\right)$ and increased significantly in all groups $(\mathrm{P}<0.01)$ at the time of implant removal viz $1.80 \pm$ $0.35 \times 10^{5}, 2.22 \pm 0.57 \times 10^{5}, 2.58 \pm 0.71 \times 10^{5}$ and $2.36 \pm 0.63 \times 10^{5}$ respectively in CIDR, TRIU-B, $\mathrm{P}_{4}$ Sponge, and control groups. As expected, after 48 hours of implant removal, total bacteria count obtained was significantly similar viz $\left(2.71 \pm 0.71 \times 10^{4}, 2.85 \pm 0.78 \times 10^{4}\right.$ and $2.96 \pm 1.2 \times 10^{4}$ ) to that as obtained before implant insertion in all the groups of animals but in Control group (placebo) the total bacterial count was significantly $(\mathrm{P}<0.01)$ higher $\left(2.02 \pm 0.25 \times 10^{5}\right)$ even after 48 hours after the implant removal. Furthermore, there was no significant difference $(\mathrm{P}>0.05)$ in total bacterial count even at the time of removal and 48 hours after insertion between CIDR, $\mathrm{P}_{4}$ Sponge, TRIU-B and Placebo groups but the total bacterial count in placebo group was significantly higher $(\mathrm{P}<0.001)$ at 48 hours after sponge removal than those of $\mathrm{CIDR}, \mathrm{P}_{4}$ Sponge and TRIU-B groups as shown in Table 1 and Fig. 3.

Table.1 Total bacterial counts (Mean \pm SE) obtained from the vaginal swabs

\begin{tabular}{|l|l|l|l|}
\hline Group & $\begin{array}{l}\text { TBC at the time of } \\
\text { implant insertion }\end{array}$ & $\begin{array}{l}\text { TBC at the time of } \\
\text { implant removal }\end{array}$ & $\begin{array}{l}\text { TBC after 48 hours of } \\
\text { implant removal }\end{array}$ \\
\hline CIDR Protocol & $2.15 \pm 0.53 \times 10^{4 \mathrm{Aa}}$ & $1.80 \pm 0.35 \times 10^{5 \mathrm{Ab}}$ & $2.71 \pm 0.71 \mathrm{X} 10^{4 \mathrm{Aa}}$ \\
\hline TRIU-B Protocol & $2.14 \pm 0.40 \mathrm{X} 10^{4 \mathrm{Aa}}$ & $2.22 \pm 0.57 \mathrm{X} 10^{5 \mathrm{Ab}}$ & $2.85 \pm 0.78 \mathrm{X} 10^{4 \mathrm{Aa}}$ \\
\hline P $_{\mathbf{4}}$ Sponge Protocol & $2.33 \pm 0.68 \times 10^{4 \mathrm{Aa}}$ & $2.58 \pm 0.71 \mathrm{X} 10^{5 \mathrm{Ab}}$ & $2.96 \pm 1.2 \mathrm{X} 10^{4 \mathrm{Aa}}$ \\
\hline Blank Sponge & $2.24 \pm 0.92 \times 10^{4 \mathrm{Aa}}$ & $2.36 \pm 0.63 \times 10^{5 \mathrm{Ab}}$ & $2.02 \pm 0.25 \mathrm{X} 10^{5 \mathrm{Bb}}$ \\
\hline
\end{tabular}

Mean \pm SE bearing different superscript $(\mathrm{a}, \mathrm{b}, \mathrm{c})$ vary significantly $(\mathrm{P}<0.01)$ within the group; and with different superscript $(\mathrm{A}, \mathrm{B}, \mathrm{C})$ vary significantly $(\mathrm{P}<0.01)$ between the groups. $\mathrm{TBC}=$ Total bacterial count 
Fig.1 (A) Preparation of Perineal region for collection of Vaginal swabs. (B) Collection of samples by Moistened Cotton Swab (Normal saline)

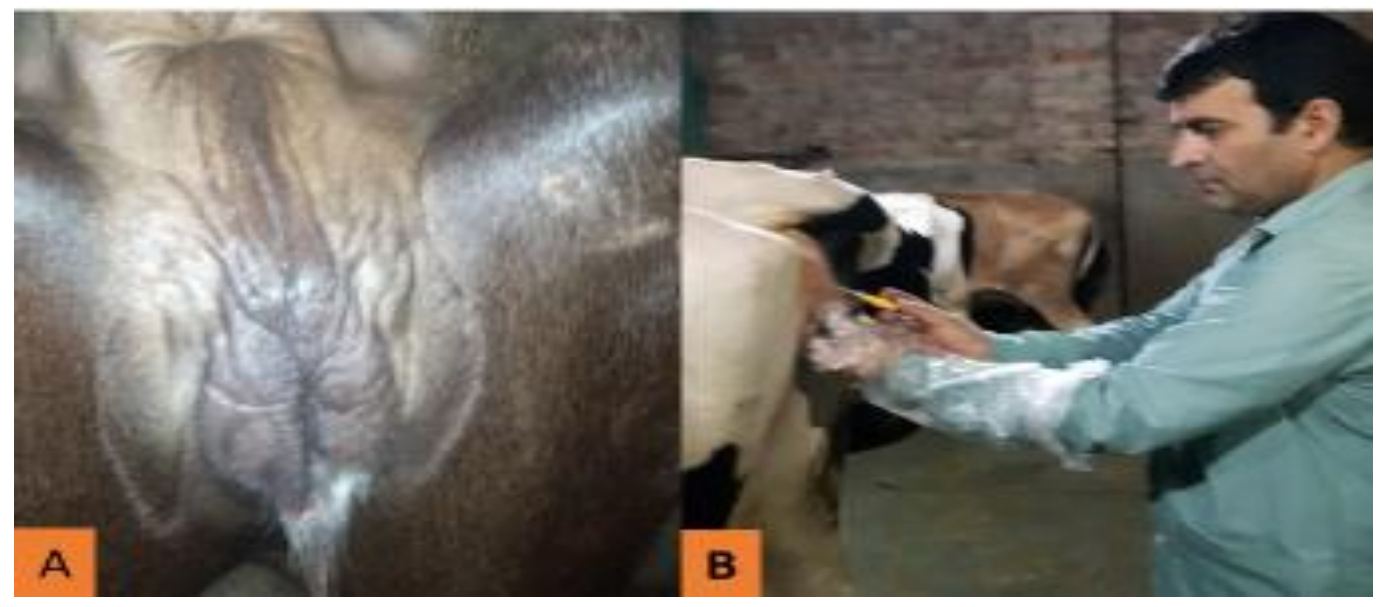

Fig.2 (A) Serially diluted from $10^{-1}$ to $10^{-6}(\mathrm{~B})$. Standard Plate Count Media used manual bacterial colony count procedure

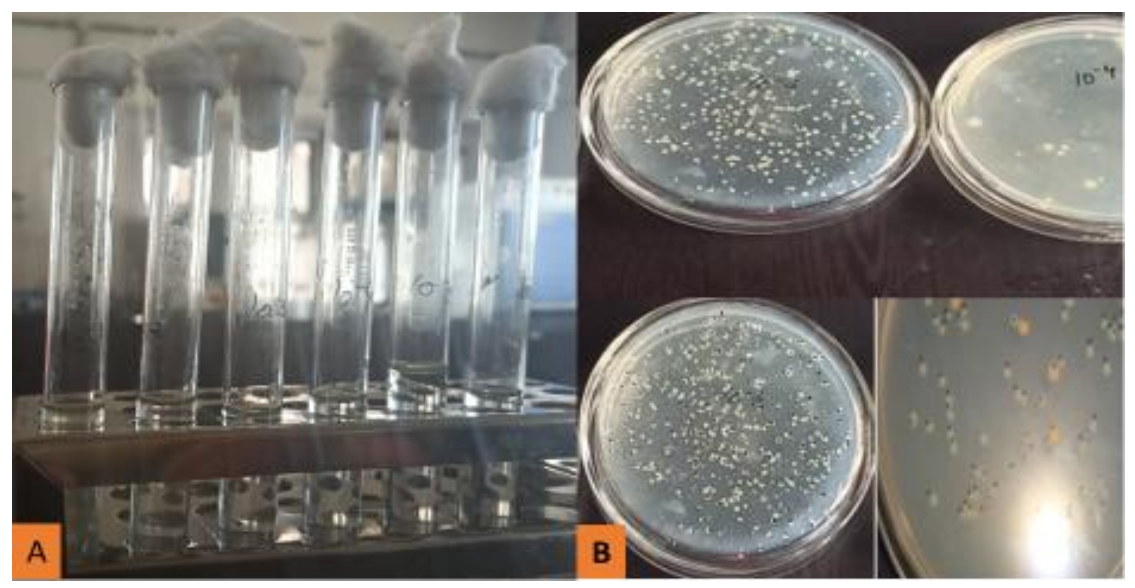

Fig.3 Bar diagram showing total bacterial counts obtained from the vaginal swabs

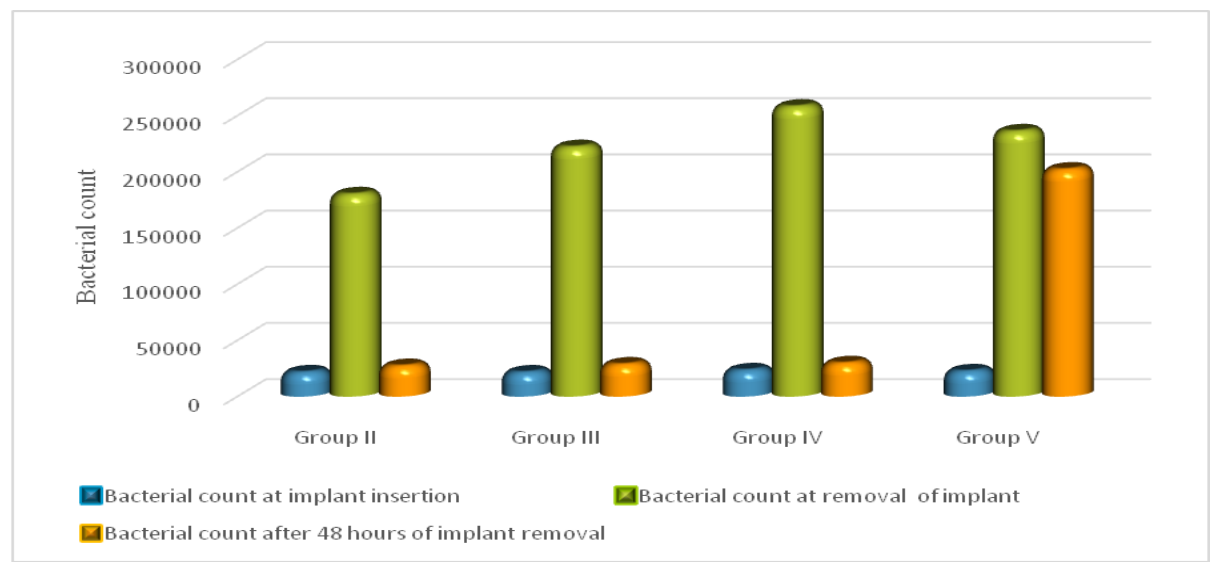


The total bacteria count obtained from samples collected on day 0 was significantly similar between all treatments and increased significantly in all groups at the end of the period (D9; day of implant/sponge withdraw). However, two days after implant/sponge removal the vaginal bacterial population returned to levels similar to those observed prior to their insertion but in Control group (placebo) the total bacterial count was significantly $(\mathrm{P}<0.01)$ higher $\quad(2.02 \pm$ $0.25 \times 10^{5}$ ) even after 48 hours after the implant removal. These results are in agreement with those observed by Martins et al., (2009), Amin (1996), Martins et al., (2010) and Mohammed et al., (2017). This reduction in the CFU may be due to the removal of the irritating agent (sponge, or vaginal implant) and promoted by the increase in local immune response caused by the estrogenic effects during proestrus and estrus phases. Suarez et al., (2006) reported that hormonal changes status such as estrus cycle could have effect on vaginal bacterial population especially when progesterone levels were high. In the present study, in control group the load remained significantly high even on day 11/12 (day of estrus in other groups) as no estrogenic effect occurs in this group as there was no induction of estrus occurs in this group. The use of intravaginal implants/sponges stimulates a localized inflammation with the accumulation of a less foul-smelling fluid and a significant increase in bacterial load (Motlomelo et al., 2002; Romano, 2004). Suarez et al., (2006) hypothesized that the bacteria present at the time of intravaginal sponge insertion and its by-products could later promote further inflammation. The presence of a foreign body (CIDR, TRIU-B and $\mathrm{P}_{4}$ Sponge) in the vaginal cavity increased the local mucous secretion. The increase in bacteria counts was well expected after the use of sponges (Amin, 1996; Martins et al., 2009), even after different periods into the vagina (Suarez et al., 2006). From sponge withdrawal, a drastic decrease in bacterial count was recorded, reaching the day of estrus levels, similar to those observed before intravaginal sponge insertion. The drastic decrease in total bacterial count is due to increase in WBC content of the vagina stimulated by the increase in estrogen levels due to induction of estrus. The predominant presence of polymorphonuclear leucocytes was observed in the vagina of the sponge-treated ewes (Ahern 1976). It is speculated that this may contribute to the very fast clearance of the bacterial load observed after sponge withdrawal. The volume of vaginal flow and the bacterial load reached peak from sponge insertion day 9 at the day of implant removal (Ungerfeld and Rubianes, 1999, 2002).

It was concluded the insertion of implants/ Sponge inside vagina becomes source of introduction of bacteria inside the vagina and generates increase in bacterial flora (approximately 10-fold). This effect is similar irrespective of whether intravaginal sponges were used, blank sponges were used or progesterone implants were used. Hormones also has influence on the bacterial load of vagina, regardless of their origin (synthetic or natural), progesterone is conducive for multiplication of bacteria while as estrogenic environment causes rapid decrease in vaginal bacterial load. The bacterial load drastically decreased after implant/sponge withdrawal, reaching normal values on the day of estrus. In control group, there was no induction of estrus, the load remained significantly high even on day 11/12 (day of estrus in other groups) as no estrogenic effect occurs in this group and hence no clearance of bacterial load takes place.

\section{Acknowledgments}

The authors are responsible for all the content. 


\section{Conflict of interest}

The authors declare that they have no conflict of interest.

\section{Funding information}

This work was supported by Faculty of Veterinary Sciences and Animal Husbandry, RS pura SKUAST J, Jammu and Kashmir India.

\section{References}

Amin, J.D. 1996. Effect of fluorogesterone acetate impregnated intravaginal sponges on vaginal bacterial flora of ewes. Nigerian J. Anim. Prod. 23, 98100.

Ahern, C.P., 1976. The bacteriology of vaginal mucus and intravaginal sponges from sheep and the effect of coating sponges with antibacterial agents. Irish Vet. J. 30, 111-117

Hafez, E.S.E. 1993. Anatomy of female reproduction. In Reproduction in Farm Animals. 6th Edn. Philadelphia: Lea and Febiger. Pp. 53-54.

Hafez, E.S.E. and Hafez, B. 2002. Functional anatomy of reproduction: In Reproduction and Artificial Insemination in Animals. 7th Edn., Mc Graw-Hill Publishers. pp 519

Manes J, Fiorentino MA, Kaiser G, Hobor F, Alberio R, Sanchez E, et al. 2010. Changes in the aerobic vaginal flora after treatment with different intravaginal devices in ewes. Small Rum. Res. 94, 201-204.

Mansano, C.F.M., Simon, H.M., Mukai, L.S., Peres, A.R. and Macente, B.I. 2013. Effect of two protocols for synchronization of estrus in female bovine on pregnancy rate to first service. Rev. Bras. Reprodução Anim .37(3): 278-284.
Martins G, Figueira L, Penna B, Brando F, Varges R, Vasconcelos C, et al. 2009. Prevalence and antimicrobial susceptibility if vaginal bacteria from ewes treated with progestinimpregnated intravaginal sponges. Small Rumin. Res. 81, 182-184.

Martins, L. T., Neto, P. C. S., Neto, S. G., Rauber, L. P., Bertolini, M., Vieira, A. D. and Mezzalira, A, 2010. Microbiological and functional evaluation of an alternative device (OB) ${ }^{\circledR}$ for estrous synchronization in ewes. Cienica- Rural, Santa Maria 40 (2): 389-395.

Mohammed, K.M. Nabih, A.M and Darwish, G.M. 2017. Efficacy of anti-microbial agents on the vaginal microorganisms and reproductive performance of synchronized estrus eves. Asian Pacific Journal of Reproduction 6(3): 121-127. Motlomelo, K.C., Greyling, J.P.C and Schwalbach, L.M.J. 2002. Synchronisation of oestrus in goats: The use of different progestagen treatments. Small Rumin. Res. 45, 4549.

Norman, H.D., Wright, J.R., Hubbard, S.M., Miller, R.H., Hutchison, J.L., 2009. Reproductive status of Holstein and Jersey cows in the United States. J. Dairy Sci. 92, 3517-3528.

Otero, C., Saavedra, L., Silva De Ruiz, C., Wilde, O., Holgado, A.R. and NaderMacias, M.E. 2000. Vaginal bacterial microflora modifications during the growth of healthy cows. Lett Appl Microbiol 31, 251- 254.

Penna, B., Libonati, H., Director, A., Sarzedas, A.C, Martins, G., Felipe Z, et al. 2013. Progestin-impregnated intravaginal sponges for estrus induction and synchronization influences on goats vaginal flora and antimicrobial susceptibility. Anim Reprod Sci. 142, 71-74 
Romano, J.E. 2004. Synchronization of estrus using CIDR, FGA or MAP intravaginal pessaries during the breeding season in Nubian goats. Small Rumin. Res. 55, 15-19.

Shart, R. E., Bellow, E. L., Starhgmuller R. B. and Custer, E. E. 1990. Physiological mechanism controlling an oestrous and fertility in postpartum beef cattle. $\mathrm{J}$. Anim. Sci. 55, 799- 816.

Snedecor, G.W. and Cochran, W.G. 1986. In Statistical Methods. 8th Edn. Iowa State University Press, Ames, Iowa, USA.

Suareza, G. Zuninob, P. Carolc, H. and Ungerfeld, R. 2006. Changes in the aerobic vaginal bacterial mucous load and assessment of the susceptibility to antibiotics after treatment with intravaginal sponges in anestrous ewes. Small Rumin. Res. 63, 39-43.

Ungerfeld, R. and Rubianes, E. 1999.

Effectiveness of short progestogen priming for the induction of fertile oestrus with eCG in ewes during late seasonal anoestrus. Anim. Sci. 68, 349-353.

Ungerfeld, R. and Rubianes, E. 2002. Short term primings with different progestogen intravaginal devices (MAP, FGA, CIDR) for eCG estrous induction in anestrus ewes. Small Rumin. Res. 46, 61- 64.

Walsh, R.B. 2008. Safety of a progesteronereleasing intravaginal device as assessed from vaginal mucosal integrity and indicators of systemic inflammation in postpartum dairy cows. The Canadian Journal of Veterinary Research 7, 43-49

Williams, G. L. 1990. Suckling as a regulator of postpartum rebreeding in cattle: A review. J. Anim. Sci. 68, 831-52.

\section{How to cite this article:}

Syed Ehtisham Hussain Andrabi, Utsav Sharma' Anil KumarPandey and Sharad Kumar. 2020. The Effect of Treatment by Intravaginal Progesterone Implants in Postpartum Anestrus Cows on the Changes of the Vaginal Bacterial Load. Int.J.Curr.Microbiol.App.Sci. 9(09): 1259-1265. doi: https://doi.org/10.20546/ijcmas.2020.909.154 